\title{
THE EFFECTS OF SOME AGRI FOOD TRADE RELATIONSHIPS CONCERNING BREXIT IN EASTERN EUROPEAN COUNTRIES ${ }^{1}$
}

\author{
Key words: the United Kingdom, Brexit, trade, Visegrad Countries
}

\begin{abstract}
The aim of the study is to examine which part of agricultural and food trade between Visegrad countries and the United Kingdom is threatened by Brexit. On 23 June 2016, the United Kingdom voted in a referendum to leave the European Union, but this has not yet taken place, though it should have happened by 29 March 2019. Therefore, it remains uncertain and the conditions the exit remain to be seen. In the absence of a final agreement, it is only possible to determine currently competitive sectors that could remain in this situation in the future, too. Competitiveness studies can provide guidance to determine expected effects. For products with a lower competitiveness value, turnover is expected to decrease due to changing regulations or increasing duties. Based on the long-term analysis of agri-food trade values of the parties, it is clear that markets are sufficiently diversified. So British withdrawal will not result in significant consequences in the case of Visegrad countries. In terms of trade relations, highly processed products are expected to be competitive in the future.
\end{abstract}

\section{INTRODUCTION}

It is commonly known that the United Kingdom (UK) had been due to leave the European Union (EU) on 29 March 2019, two years after it started the exit process by invoking Article 50 of EU's Lisbon Treaty ${ }^{2}$. Despite the withdrawal agreement [EC 2019b] reached between the EU and UK, the fifty-seventh Parliament of the United Kingdom rejected it three times. Therefore, the first time round, EU leaders granted an initial extension of the Brexit process until 12 April 2019. After this, at the special summit on 10 April, EU leaders agreed on an extension of Article 50 until the end of October $2019^{3}$. It can be seen that despite the draft agreement on the technical conditions for exit, political uncertainty in the UK has increased. On the other hand, it is difficult to see a solution

The study was made with the support of the Bolyai János Research Scholarship.

2 As a result of a longer preparation process, on 23 June $2016,51.9 \%$ of UK voters voted to leave the $\mathrm{EU}$ in the form of a referendum. The referendum turnout was $71.8 \%$ [BBC 2016].

3 On 10 April, EU leaders agreed an extension of Article 50 until the end of October 2019. If the agreement is ratified by both sides earlier, the UK will leave on the first day of the following month [European Council 2019]. 
to this situation, since the British Prime Minister, Theresa May, resigned from her post as head of government on Friday, 24 May. The next prime minister is expected to take over on July 24, 2019. It is expected that the position will be filled by a potential no-deal promoter Boris Johnson, the former foreign minister [Vox.com 2019]. This person may further aggravate the difficulties and worries that arise as a result of radical statements that do not mitigate the tensions arising after leaving. This could result in a hard Brexit and even a drastic "no deal".

The United Kingdom's share of total intra-EU (i.e. internal market) imports of agrifood accounts for about $10 \%$, while the same share for exports is less than $5 \%$, on average (Table 1). Meanwhile, V4 countries did not reach $9 \%$ of imports, while intra-EU exports

Table 1. The United Kingdom and V4's volume and share in agricultural and food trade within the EU (2018)

\begin{tabular}{|l|r|r|r|r|r|r|}
\hline \multirow{2}{*}{ Denomination } & \multicolumn{5}{|c|}{ Import } & \multicolumn{3}{c|}{ Export } \\
\cline { 2 - 7 } & $\begin{array}{c}\text { intra- } \\
\text { EU-28 }\end{array}$ & $\begin{array}{c}\text { extra- } \\
\text { EU-28 }\end{array}$ & total & $\begin{array}{c}\text { intra- } \\
\text { EU-28 }\end{array}$ & $\begin{array}{c}\text { extra- } \\
\text { EU-28 }\end{array}$ & total \\
\hline \multicolumn{7}{|c|}{ Trade volume [bln EUR] } \\
\hline EU28 & 389.4 & 137.6 & 527.0 & 391.3 & 137.3 & 528.6 \\
\hline The United Kingdom & 41.06 & 16.25 & 57.31 & 16.75 & 10.25 & 27.00 \\
\hline The Czech Republic & 8.3 & 0.5 & 8.9 & 6.7 & 0.6 & 7.3 \\
\hline Hungary & 5.4 & 0.5 & 5.9 & 7.5 & 1.3 & 8.8 \\
\hline Poland & 16.0 & 3.8 & 19.7 & 24.1 & 5.2 & 29.3 \\
\hline Slovakia & 4.4 & 0.1 & 4.5 & 2.7 & 0.1 & 2.8 \\
\hline V4 countries & 34.2 & 4.9 & 39.0 & 40.9 & 7.2 & 48.1 \\
\hline \multicolumn{7}{|c|}{ Share of EU-28 [\%] } \\
\hline The United Kingdom & 10.55 & 11.81 & 10.87 & 4.28 & 7.47 & 5.11 \\
\hline The Czech Republic & 2.14 & 0.39 & 1.68 & 1.70 & 0.45 & 1.37 \\
\hline Hungary & 1.40 & 0.33 & 1.12 & 1.91 & 0.94 & 1.66 \\
\hline Poland & 4.11 & 2.73 & 3.75 & 6.15 & 3.80 & 5.54 \\
\hline Slovakia & 1.13 & 0.10 & 0.86 & 0.69 & 0.08 & 0.53 \\
\hline V4 countries & 8.77 & 3.55 & 7.41 & 10.45 & 5.27 & 9.11 \\
\hline
\end{tabular}

Source: own editing based on Eurostat data

4 In terms of the potential economic scenario of Brexit, the fundamental issue is the relationship to the internal market based on the four freedoms after the termination of British membership. If, after legal separation, the United Kingdom were (to some extent) part of the internal market, it would not be excluded from the system of European integration in the economy. The latter is called soft Brexit. While the irreversible abandonment of the internal market is the hard Brexit. Failure to agree on exit conditions by the exit date could lead to the more serious changes to EU Member States without a comprehensive deal and without an exhaustive regulatory agreement (no deal), which could result in a number of specific technical difficulties [EC 2017, 2019a]. 
exceeded $10 \%$, exceeding British values. Outside the EU, it can be seen from trade that the UK is also more able to import and export. In the case of imports, the Aegean kingdom has a threefold surplus and a 30\% surplus on exports compared to the total V4. It is still not surprising that the role of Poland within the group of countries is decisive [Vásáry 2018].

In 2000, 59.4\% of British exports flow to the EU (intra-EU traffic). By the end of the period, this ratio increased to $62.0 \%$, in 2018. Growth has been achieved despite increasing effectiveness of EU trade policy and a growing number of trade agreements (e.g. the Ukraine, Canada), the economic strengthening of former colonies, the results of exchange rate effects or globalization. Parallel to this, the share of imports from the second largest importing country in the EU (after Germany and before the Netherlands) increased by $54 \%$ compared to 2000 . Nevertheless, looking at the balances of intra-EU trade in EU Member States, the UK's foreign trade deficit is the largest in the EU-28 (Figure 1).

UK imports of agricultural and food products have doubled (112\%) over the 18 years under review, while exports of this product range have increased by only $62 \%$. A significant part of British foreign trade is focused on processed and/or finished products. Quantitative analysis of exports shows that bulk goods, such as cereal, represent the largest batch, but in 2018, drinks jumped to the top [Eurostat 2019, Vásáry 2019]. The amount of other processed products is also significant. Similar products appeared in imports, along with fresh goods (e.g. meat, milk and vegetables). As the share of these product lines is decisive, countries that move to the UK can also feel market shrinkage.

Germany, the Netherlands and France are the UK's largest EU member state trading partners. Consequently, Brexit may be mostly affected by these Member States. Bilateral trade of these countries with the United Kingdom accounts for $50 \%$ of the total EU-27

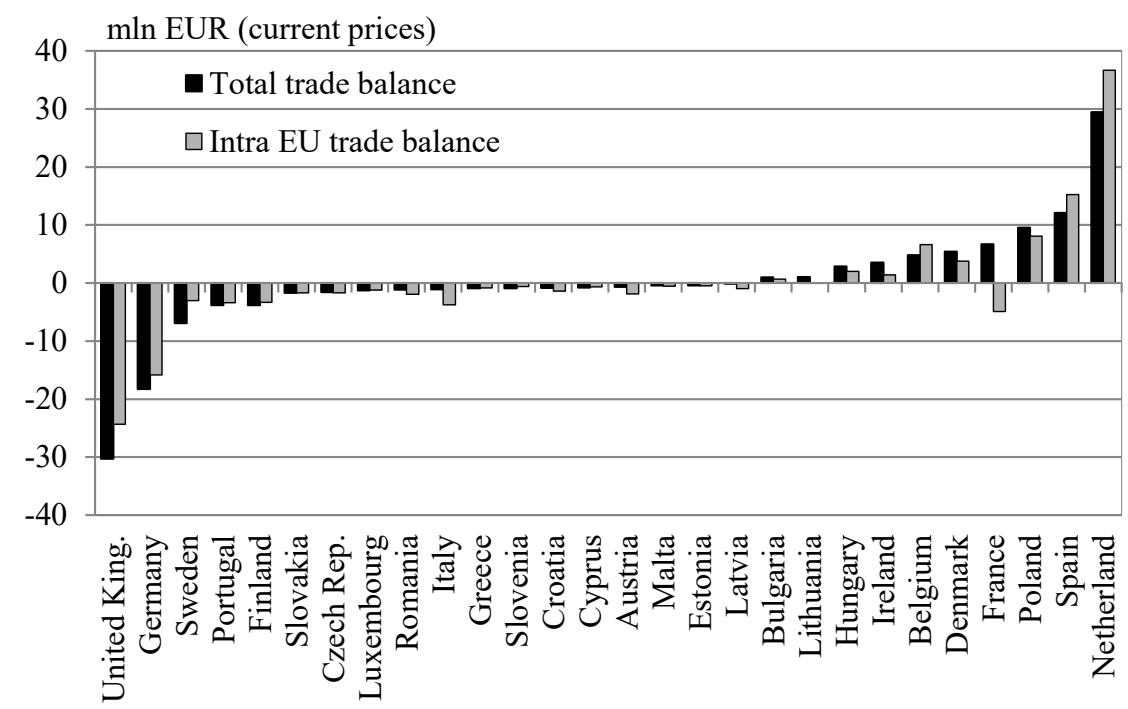

Figure 1. The trade balance of agicultural and food products in EU Member States (2018) Source: own elaboration based on Eurostat data 
bilateral exchange. This ranking remains unchanged for exports and imports. Only considering agri-food trade, France and the Netherlands are the UK's main partners. Ireland will replace Germany in third place. The three major partners account for half of British imports and exports in the agro-food sector ${ }^{5}$.

In examining intra-EU trade in Visegrad countries, it can be concluded that, as a consequence of Brexit, as in the past, continuously increasing trade related to agicultural and food products may significantly change. Using mutual benefits, all parties were able to significantly increase their commercial activity, and - in the case of the whole EU - V4 countries were able to expand their trade processes. Regarding the British relationship - thanks to the EU single market - all parties increased their turnover in quantity and value, too ${ }^{6}$.

But the question arises: if the relationship between the United Kingdom and the other countries, especially Visegrad Countries, is already known, then it would be worth examining which major commodity groups can become competitive after Brexit. Therefore, in light of this trail of thought, the main characteristics of each product group will be reviewed for Visegrad countries.

\section{MATERIAL AND METHODS}

In order to present foreign trade processes, it is necessary to use the database of the European Union Statistical Office [Eurostat 2019]. This will enable the UK market to be presented and the values of the effects related to the EU and V4 to be processed. Following Eurostat data, the extent and timing of bilateral trade in goods can be quantified. Prior to presenting the results, however, it is necessary to enumerate some fundamental conditions:

1. For country-by-country data, a breakdown by sector and product ranges is based on SITC (Standard International Trade Classification) and freight rates are available in the harmonized system. The analysis only examines data available on agri-trade. Other factors are difficult to compare due to a lack of harmonized data.

2. Within territorial demarcation, the paper focuses on Visegrad Countries (the V4 - the Czech Republic, Hungary, Poland and Slovakia).

3. During the examination of the trade process between the United Kingdom and other Member States, the following specifics shall not be taken into account, namely: the distorting effects of VAT fraud on the internal market or illegal trade in certain sectors, the fluctuation of exchange rates, and the phenomenon that intra and extra EU trade that values in many cases do not indicate that the country of entry or exit or the

5 Ireland's trade with the United Kingdom is special following of the geographical conditions. If we seeing the import, we can $27 \%$ of Ireland's EU imports come from the UK and $46 \%$ of total Irish food imports go to the United Kingdom - In case of other European countries this is just 4\% on average [Eurostat 2019].

6 Poland is the most affected member state due to Brexit changes, as Poland currently is the most important partner from this region. Due to transformation effects, all V4 countries can register a decline related to UK export. This process could result in significant market transformation [Vásáry 2019]. 
country of destination are the same ${ }^{7}$. A loading site will be taken into account on the basis of the statistical register, although it will be further transported to other countries in the internal market.

The following hypotheses need to be tested:

- H1: Are V4 countries exposed to Brexit?

- H2: Do processed products already have a competitive advantage? (this represents a reserve for competitiveness);

- H3: Due to direct trade PL is the most vulnerable of all V4s.

Further restrictions needed to be done in pursuance of the study as well. In this framework, the processes appearing in individual countries in relation to the UK and the V4 can be examined. Several method function verbs and indices were used during analysis. The export-import balance that depicts the country's export import difference.

$$
B_{E / I}=x_{i j}-m_{i j}
$$

where: $i$ is the given country, $j$ is the given product, $x$ is export, $m$ is import, $B_{E / I}$ gives the sum of balance, $x_{i j}$ is the sum of export value of the given country, and $m_{i j}$ is the sum of similar values of import [Poór 2010].

The second index is the export import ratio. The ratio is the simplest export specific index that correlates the exports of countries to imports [Poór 2010]:

$$
R_{E / I}=\frac{x_{i j}}{m_{i j}}
$$

where $R_{E / I}$ is the value of index, $x_{i j}$ is the sum of export items, currently the sum of export values of the given country, while $m_{i j}$ gives the sum of similar values of import.

The analysis covers the calculation of the Herfindahl-Hirschman-index $(H H I)$ of the countries examined as well, which basically determines the scale of market share [Poór 2010]. During this, the export share of individual countries can be squared and the values received this way added up. Formally we form the index the following way:

$$
H H I=\sum_{i=1}^{N} S_{i}^{2}
$$

where $S_{i}$ is the market share of a given $i$ product group. Subsequently, the value of the index is between 0 and 1 . Higher values indicate a higher level of concentration. If the index is closer to 1 , the product's concentration is higher, if it is closer to 0 , concentration is lower.

7 For example, the ports of Belgium (e.g. Antwerp) and the Netherlands (e.g. Rotterdam) are dominant transit hubs in the EU, therefore UK, Europe-wide and global trade flows through these harbours, which means that statistical values could significantly be distorted, as these countries are not primary producers, they are only primary recipients within the EU, which unduly appreciates their statistical significance. 
The examination is ended with the index developed by Béla Balassa for measuring comparative advantages [Balassa 1965]. The formula of the $B$ index is as follows:

$$
B=\frac{x_{i j} / \sum_{i} x_{i j}}{\sum_{j} x_{i j} / \sum_{i} \sum_{j} x_{i j}}=\frac{x_{i j} / \sum_{j} x_{i j}}{\sum_{i} x_{i j} / \sum_{i} \sum_{j} x_{i j}}
$$

where $x$ indicates export, $i$ is for product group, $j$ is the examined country, and, subsequently, $x_{i j}$ reflects product-level, while $\sum_{i v} x_{i j}$ is the total export of a given country, $\sum_{j} x_{i j}$ indicates the product-level export, and $\sum_{i} \sum_{j} x_{i j}$ is the total export of the world or country group.

Index $B$ proceeds that the structure of export is sensitive to relative costs and the differences are present in non-price-like factors. So, the comparative benefits will probably define the structure of export. In the course of this study, the focus will be the value of trade with the UK as a point of reference. There are two options to examine comparative benefit. On the one hand, it can be analysed by measuring how the export share of a given product or product group correlates to the export share on the reference market (UK), enabling a regional comparison of the relative sum of values. On the other hand, based on the second half of the formula, how the product export ratio of source countries (the V4) turns out within the whole export (UK) can be analysed. There is a comparative benefit when the share of the export product group is larger than that of the basis of comparison, and when the share of the analysed country is larger than the value within the whole export. The numerator and denominator of the Balassa index is between 0 and 1. Accordingly, the value of the index can be within $[0 ; \infty]$ interval. If $B>1$, the given country has a comparative advantage with respect to the examined product. If the value of the index is between 0 and 1, a comparative disadvantage is reflected. The index is asymmetric in its structure because it is only limited from the bottom which results in skew dispersion in the positive range. The problem is handled based on the revealed symmetric comparative advantage (RSCA) developed by Bent Dalum et al. [1988].

$$
R S C A=\frac{(B+1)}{(B-1)}
$$

\section{RESULTS}

If we look at the trade processes of Visegrad countries, it is observed that the volume of bilateral traffic has increased in terms of intra-EU trade, on average, over the period under review (Figure 2). The biggest rise can be seen in Poland, but other countries have been able to increase their value of trade with the UK. At the same time, it can be observed that imports of V4 countries have increased significantly more than exports. So, these countries were able to take advantage of the single internal market and find new markets and sales opportunities on the other side of the European Union. It is also clear that the products of the V4 countries, in particular Poland, were very capable of meeting British market conditions. 
V4 share in UK import from the EU

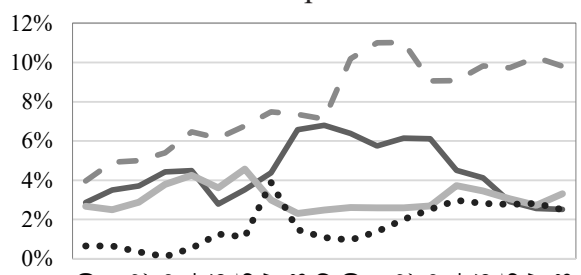

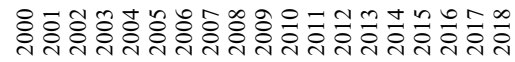

- CZ IM

$\ldots$ HU IM
V4 share in UK export from the EU

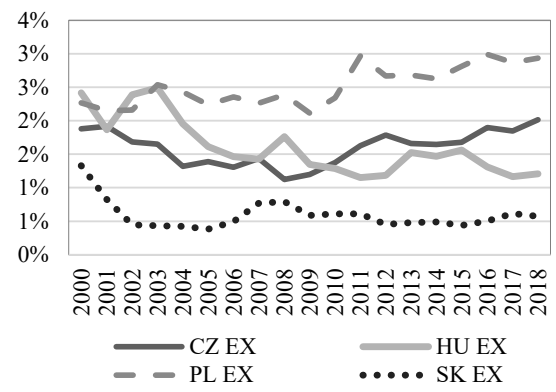

Figure 2. The share of V4 in total UK agro-food trade with EU countries (2000-2018)

Source: own elaboration based on Eurostat data

New markets have led to a dramatic increase in the trade deficit in agricultural and food products (Figure 3). In other words, the demand for Eastern European products has increased, these products have been increasingly able to meet EU standards, substantially expanding and stabilizing their competitive position ${ }^{8}$. Although, it is also observed that the three smaller Member States of the four countries can only show moderate results. This will result in a commercial surplus against the UK.

On the basis of the export import indicator, it can be seen that

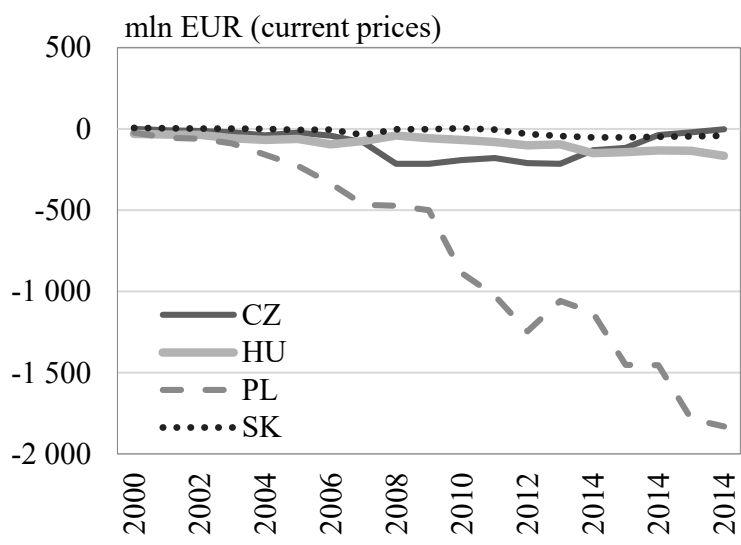

Figure 3. UK agro-food trade balance with V4 countries (2000-2018)

Source: own elaboration based on Eurostat data the two-way trade between the countries has gradually become more balanced. It has a unique pattern in Slovakia, which, due to slightly more difficult trading conditions in the pre-accession period, was unable to deliver to the British market in significant volume, thus resulting in a disproportionately high indicator (Figure 4). At the same time, it can be seen that after accession, the ratio of exports and immigrants has stabilized at a significantly smooth and balanced level.

Based on $H H I$ data, it is also clear that nowadays there is no substantial concentration on exports or imports between countries (Figure 5). Hypothesis H1 is confirmed.

In this process, it is perhaps not negligible that there is an increasing demand or promotion of labour flow. Within the EU, the number of those who work in old EU Member States (EU15) and thus in the United Kingdom has increased. Many Eastern European citizens are also looking for national products abroad, and, at the same time, have promoted these as well. 


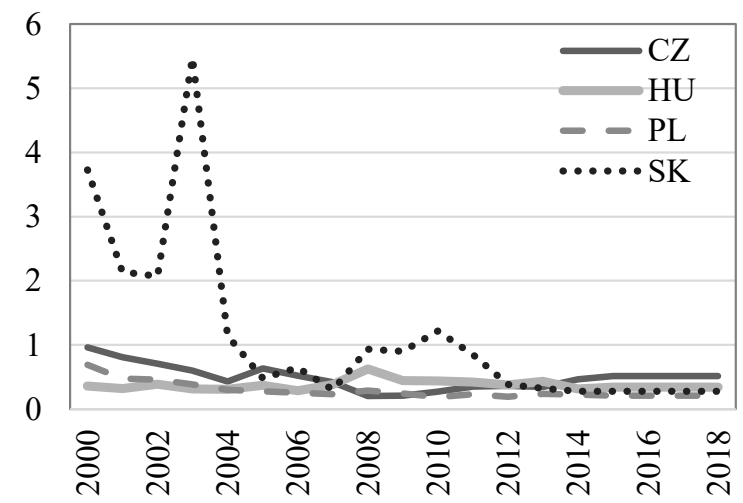

Figure 4. Export-import ratio of the V4 with the UK (2000-2018 at current prices)

Source: own elaboration based on Eurostat data

UK import

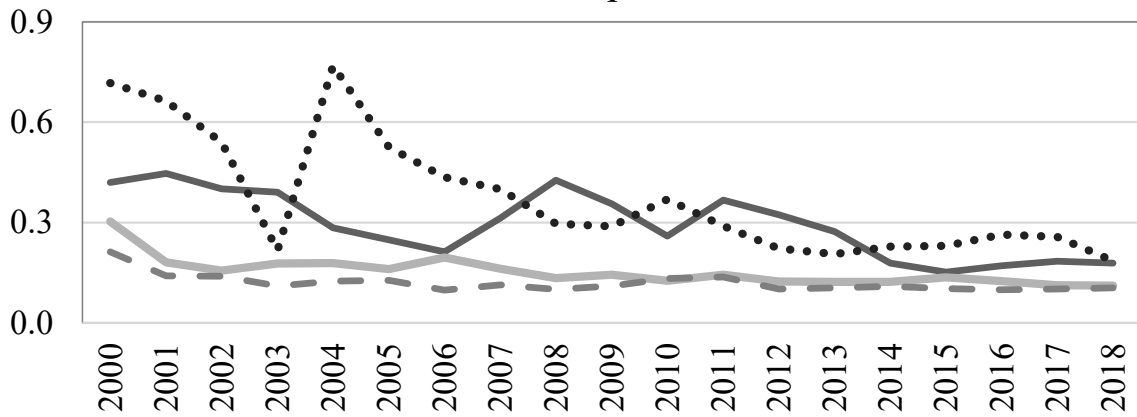

UK export

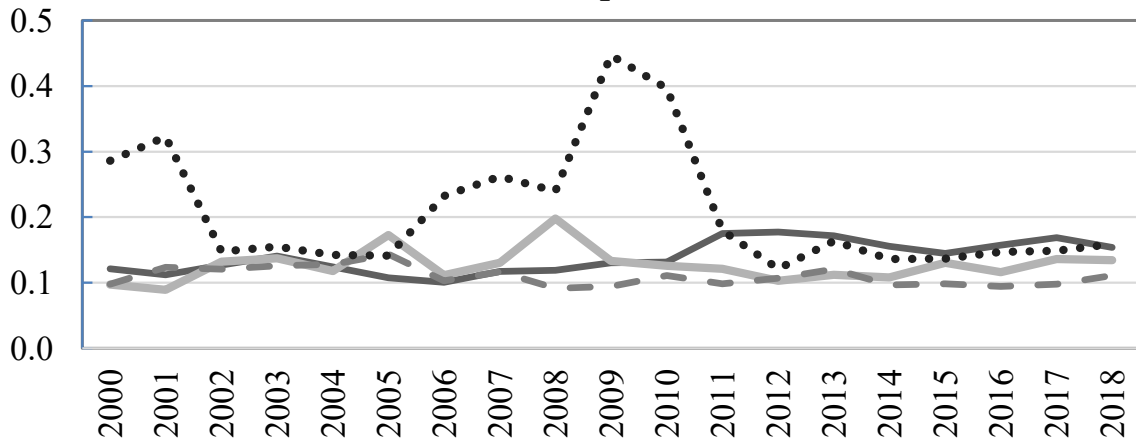

$\longrightarrow \mathrm{CZ} \quad-\mathrm{HU} \quad-\mathrm{PL} \quad \cdots \cdot \mathrm{SK}$

Figure 5. Herfindahl-Hirschman-index values in V4 countries in relation to the UK (2000-2018) Source: own elaboration based on Eurostat data 


\begin{tabular}{|c|c|c|c|c|c|c|c|c|c|c|c|c|c|c|}
\hline \multirow{4}{*}{ 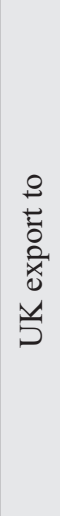 } & $\begin{array}{l}\frac{\pi}{\frac{\pi}{\pi}} \\
\frac{\pi}{\pi} \\
\frac{0}{n}\end{array}$ & $\frac{0}{\frac{1}{9}}$ & $\frac{9}{9}$ & $\stackrel{\circ}{\circ}$ & $\vec{m}$ & $\begin{array}{l}\text { to } \\
\stackrel{0}{0}\end{array}$ & $\begin{array}{l}\text { oे } \\
\text { ì }\end{array}$ & $\begin{array}{l}0 \\
\text { O̦ } \\
\text { i }\end{array}$ & $\begin{array}{l}\hat{0} \\
\dot{0}\end{array}$ & $\begin{array}{l}\circ \\
\stackrel{0}{0}\end{array}$ & $\frac{8}{7}$ & $\begin{array}{l}\stackrel{0}{0} \\
\dot{0}\end{array}$ & $\begin{array}{l}m \\
\infty \\
\dot{\varphi}\end{array}$ & $\stackrel{m}{\stackrel{0}{0}}$ \\
\hline & $\begin{array}{l}\overrightarrow{\vec{E}} \\
\frac{\overrightarrow{0}}{0}\end{array}$ & $\stackrel{n}{n}$ & 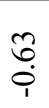 & $\stackrel{3}{0}$ & خे & $\begin{array}{l}\infty \\
0 \\
\stackrel{0}{1}\end{array}$ & $\begin{array}{l}\tilde{n} \\
\text { ? }\end{array}$ & 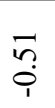 & $\frac{N}{\dot{p}}$ & $\stackrel{+}{\sim}$ & $\begin{array}{l}m \\
\infty \\
\dot{\varphi}\end{array}$ & $\stackrel{n}{o}$ & $\frac{9}{0}$ & $\begin{array}{l}\stackrel{0}{\infty} \\
\dot{0}\end{array}$ \\
\hline & 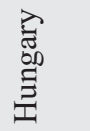 & $\stackrel{+}{n}$ & $\begin{array}{l}\infty \\
\substack{n \\
i}\end{array}$ & $\begin{array}{l}\text { రై } \\
\stackrel{0}{0}\end{array}$ & $\begin{array}{l}0 \\
\stackrel{0}{0}\end{array}$ & $\stackrel{0}{0}$ & o̊ & $\stackrel{\text { fo }}{\stackrel{f}{p}}$ & $\begin{array}{l}0 \\
\stackrel{0}{0} \\
i\end{array}$ & $\begin{array}{l}\infty \\
\infty \\
0\end{array}$ & $\hat{a}$ & $\frac{1}{0}$ & $\begin{array}{l}\stackrel{0}{\infty} \\
\dot{\varphi}\end{array}$ & $\begin{array}{l}\infty \\
\stackrel{\sigma}{0}\end{array}$ \\
\hline & 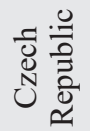 & $\begin{array}{l}\infty \\
\infty \\
0 \\
\dot{\varphi}\end{array}$ & 꼬 & 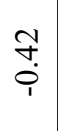 & $\begin{array}{l}\stackrel{n}{0} \\
\stackrel{1}{i}\end{array}$ & $\stackrel{m}{\circ}$ & $\begin{array}{l}\infty \\
\text { ñ } \\
? \\
i\end{array}$ & $\frac{0}{\stackrel{1}{i}}$ & $\hat{ָ}$ & $\grave{\jmath}$ & $\begin{array}{l}0 \\
\infty \\
\dot{\varphi}\end{array}$ & $\stackrel{N}{\stackrel{1}{i}}$ & $\stackrel{\sim}{\sim}$ & ले \\
\hline \multirow{4}{*}{ 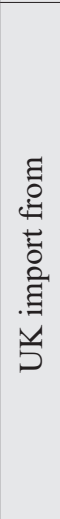 } & $\begin{array}{l}\frac{\pi}{\frac{\pi}{2}} \\
\frac{\pi}{\pi} \\
\frac{0}{\omega}\end{array}$ & $\frac{8}{7}$ & $\begin{array}{l}\infty \\
\infty \\
0\end{array}$ & $\begin{array}{l}\infty \\
\infty \\
0 \\
i\end{array}$ & $\bar{n}$ & $\frac{8}{7}$ & $\frac{8}{7}$ & $\frac{\infty}{\dot{\varphi}}$ & $\begin{array}{l}\text { oे } \\
\text { ì }\end{array}$ & $\frac{8}{1}$ & ầ & ?̊ & $\begin{array}{l}\text { مे } \\
\text { ì }\end{array}$ & $\begin{array}{l}\text { مे } \\
\text { ì }\end{array}$ \\
\hline & $\begin{array}{l}\overrightarrow{\vec{J}} \\
\frac{\overrightarrow{0}}{0}\end{array}$ & $\underset{+}{8}$ & ભે & $\begin{array}{l}00 \\
0 \\
0\end{array}$ & $\frac{n}{0}$ & $\stackrel{m}{\stackrel{0}{i}}$ & $\begin{array}{l}\infty \\
0 \\
\dot{\varphi}\end{array}$ & $\stackrel{\overbrace{}}{0}$ & $\begin{array}{l}n \\
n \\
?\end{array}$ & +o & $\begin{array}{l}\infty \\
\infty \\
\dot{\varphi}\end{array}$ & 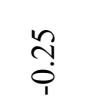 & $\begin{array}{l}0 \\
0 \\
0 \\
0\end{array}$ & $\begin{array}{l}\infty \\
\stackrel{0}{9} \\
\stackrel{1}{1}\end{array}$ \\
\hline & 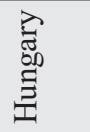 & $\frac{8}{i}$ & $\begin{array}{l}n \\
\stackrel{2}{0} \\
\stackrel{1}{1}\end{array}$ & $\hat{a}$ & $\begin{array}{l}\stackrel{0}{*} \\
\stackrel{0}{i}\end{array}$ & $\vec{a}$ & $\begin{array}{l}\infty \\
\infty \\
\dot{\varphi} \\
1\end{array}$ & $\stackrel{\text { I }}{\circ}$ & $\frac{8}{i}$ & $\begin{array}{l}\text { aे } \\
\text { in }\end{array}$ & ầ & $\frac{\infty}{\stackrel{\infty}{i}}$ & $\begin{array}{l}2 \\
\infty \\
\dot{\varphi}\end{array}$ & $\frac{m}{\stackrel{m}{i}}$ \\
\hline & 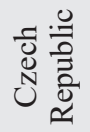 & $\begin{array}{l}\text { مे } \\
\text { ì }\end{array}$ & مे & $\underset{i}{8}$ & $\begin{array}{l}n \\
\tilde{n} \\
\stackrel{p}{1}\end{array}$ & $\begin{array}{l}n \\
0 \\
\dot{\varphi}\end{array}$ & $\vec{i}$ & $\begin{array}{l}n \\
\vdots \\
i\end{array}$ & $\begin{array}{l}n \\
\hat{o} \\
\hat{\rho}\end{array}$ & $\bar{n}$ & $\frac{\infty}{\stackrel{0}{\varphi}}$ & $\begin{array}{l}0 \\
n \\
0\end{array}$ & $\stackrel{m}{\stackrel{0}{0}}$ & م̂? \\
\hline 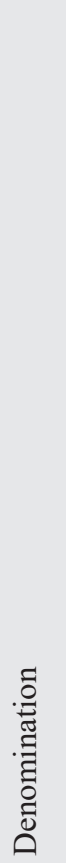 & & 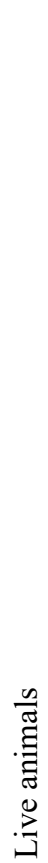 & 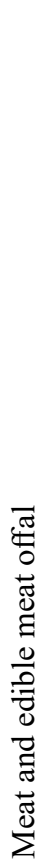 & 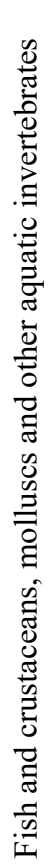 & 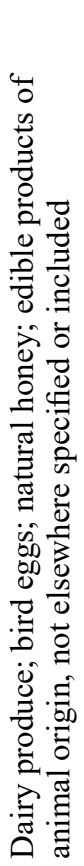 & 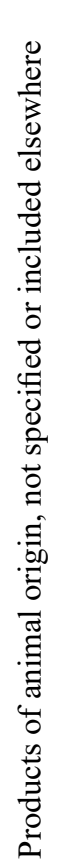 & 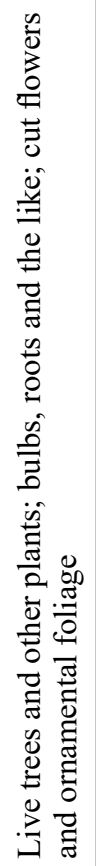 & 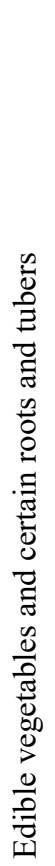 & 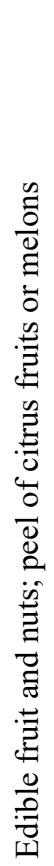 & 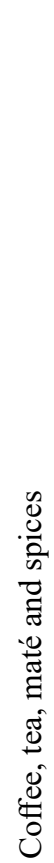 & Ũ & 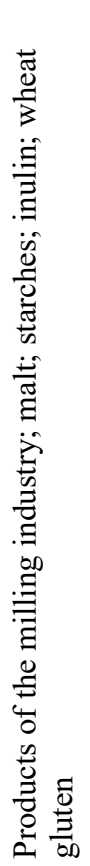 & 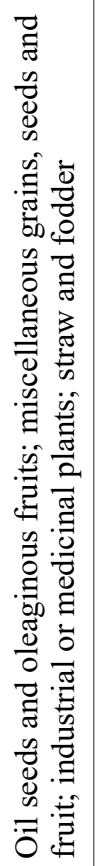 & 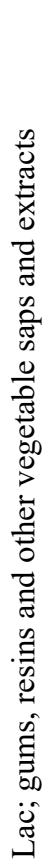 \\
\hline
\end{tabular}




\begin{tabular}{|c|c|c|c|c|c|c|c|c|c|c|c|c|}
\hline \multirow{4}{*}{ 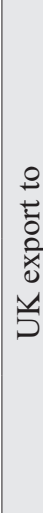 } & $\begin{array}{l}\frac{\pi}{\frac{\pi}{\pi}} \\
\frac{0}{\sigma} \\
\frac{0}{\sqrt{n}}\end{array}$ & $\begin{array}{l}\stackrel{\circ}{0} \\
\stackrel{1}{1}\end{array}$ & ஸे? & $\begin{array}{l}0 \\
+ \\
+ \\
i\end{array}$ & సે & ণิ & $\begin{array}{l}\hat{N} \\
\text { ò }\end{array}$ & $\frac{9}{0}$ & $\tilde{n}$ & $\begin{array}{l}\text { రె } \\
\stackrel{0}{0}\end{array}$ & $\begin{array}{l}n \\
\dddot{n} \\
\stackrel{1}{1}\end{array}$ & $\begin{array}{l}+ \\
\infty \\
\dot{\varphi}\end{array}$ \\
\hline & $\begin{array}{l}\vec{Z} \\
\frac{\vec{J}}{0} \\
0\end{array}$ & $\stackrel{m}{\stackrel{m}{0}}$ & $\stackrel{m}{\stackrel{0}{0}}$ & $\begin{array}{l}\tilde{n} \\
\text { in }\end{array}$ & $\stackrel{n}{\circ}$ & $\stackrel{\infty}{m}$ & 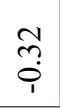 & $\begin{array}{l}\stackrel{+}{n} \\
\stackrel{1}{1}\end{array}$ & ச̆ & $\frac{n}{o}$ & $\frac{\infty}{0}$ & $\stackrel{n}{\mathfrak{i}}$ \\
\hline & 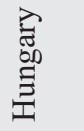 & $\begin{array}{l}\stackrel{\circ}{9} \\
\text { ì }\end{array}$ & $\hat{\hat{o}}$ & $\begin{array}{l}\bar{\sigma} \\
\dot{\varphi}\end{array}$ & $\frac{\infty}{0}$ & $\frac{N}{\circ}$ & ֻे & $\begin{array}{l}\bar{\sigma} \\
\dot{1}\end{array}$ & ?ֶ? & 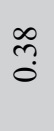 & $\begin{array}{l}\text { N̦ } \\
\stackrel{1}{1}\end{array}$ & $\begin{array}{l}\infty \\
\infty \\
i \\
i\end{array}$ \\
\hline & 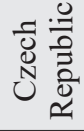 & $\begin{array}{l}\text { ก̦ } \\
\stackrel{1}{1}\end{array}$ & $\begin{array}{l}n \\
n \\
0 \\
i\end{array}$ & $\begin{array}{l}0 \\
\stackrel{0}{0} \\
\dot{1}\end{array}$ & $\begin{array}{l}\text { N̦ } \\
\text { ị }\end{array}$ & $\begin{array}{l}2 \\
\stackrel{2}{0} \\
\dot{1}\end{array}$ & $\frac{m}{\overrightarrow{0}}$ & त़ & $\tilde{n}$ & లి & $\frac{m}{0}$ & $\frac{8}{1}$ \\
\hline \multirow{4}{*}{ 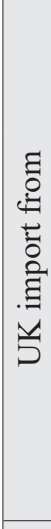 } & $\begin{array}{l}\frac{\pi}{\sqrt{3}} \\
\frac{\pi}{\pi} \\
\frac{0}{\pi}\end{array}$ & $\frac{8}{+}$ & $\frac{8}{i}$ & ले & $\tilde{0}$ & $\begin{array}{l}\text { రె } \\
\stackrel{0}{0}\end{array}$ & $\stackrel{8}{8}$ & $\begin{array}{l}\stackrel{9}{9} \\
\stackrel{1}{1}\end{array}$ & సે & $\begin{array}{l}\hat{a} \\
\hat{i}\end{array}$ & $\begin{array}{l}0 \\
0 \\
0\end{array}$ & $\underset{1}{8}$ \\
\hline & $\begin{array}{l}\vec{E} \\
\text { ज्ञ̈ } \\
\text { م }\end{array}$ & $\frac{8}{+}$ & $\begin{array}{l}n \\
\dot{6} \\
\dot{1}\end{array}$ & $\begin{array}{l}+ \\
0 \\
0\end{array}$ & $\begin{array}{l}\infty \\
\stackrel{0}{0} \\
\dot{1}\end{array}$ & $\ddot{n}$ & ㅇ. & $\frac{ \pm}{\dot{0}}$ & 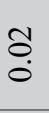 & $\begin{array}{l}n \\
n \\
i\end{array}$ & $\begin{array}{l}n \\
0 \\
0 \\
1\end{array}$ & $\stackrel{\leftrightarrow}{\stackrel{f}{*}}$ \\
\hline & 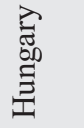 & $\frac{8}{1}$ & $\begin{array}{l}\infty \\
\infty \\
0 \\
\dot{1}\end{array}$ & 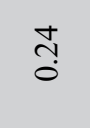 & 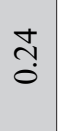 & $\begin{array}{l}0 \\
\dot{\varphi}\end{array}$ & $\begin{array}{l}n \\
\infty \\
0 \\
0\end{array}$ & $\tilde{n}$ & ֻ̃ & $\frac{1}{0}$ & $\tilde{0}$ & 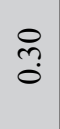 \\
\hline & 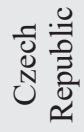 & $\begin{array}{l}\stackrel{8}{0} \\
\stackrel{0}{1}\end{array}$ & $\begin{array}{l}\stackrel{n}{0} \\
\dot{\varphi}\end{array}$ & $\stackrel{\text { fo }}{\stackrel{1}{i}}$ & $\begin{array}{l}n \\
\stackrel{\infty}{0} \\
\stackrel{0}{0}\end{array}$ & ஓे & $\begin{array}{l}\stackrel{2}{n} \\
\stackrel{0}{0}\end{array}$ & 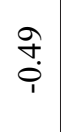 & $\underset{0}{\sharp}$ & $=$ & $\begin{array}{l}\hat{N} \\
\stackrel{1}{1}\end{array}$ & $\stackrel{m}{\stackrel{0}{i}}$ \\
\hline \multicolumn{2}{|l|}{ 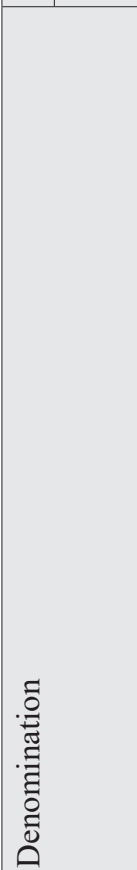 } & 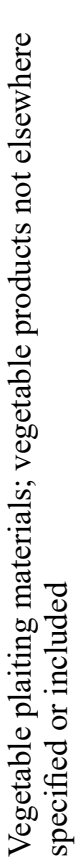 & 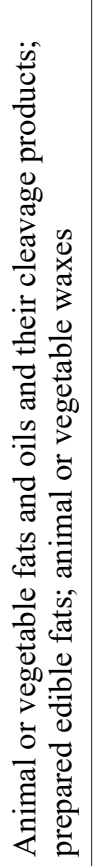 & 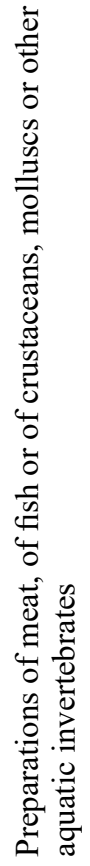 & 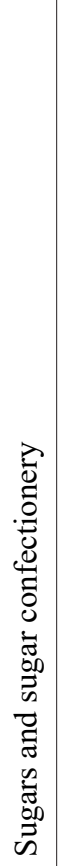 & 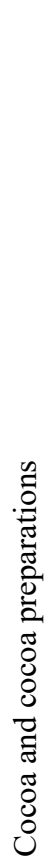 & 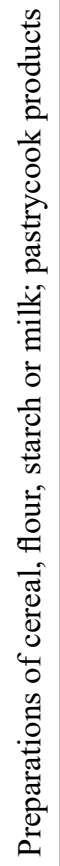 & 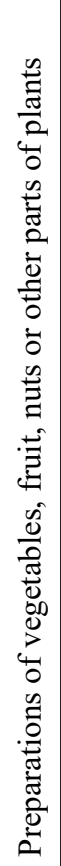 & 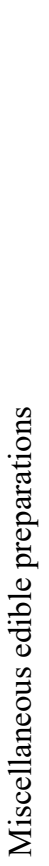 & 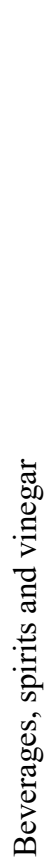 & 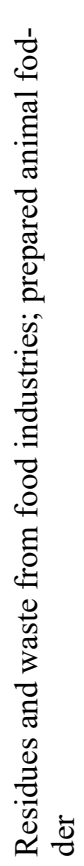 & 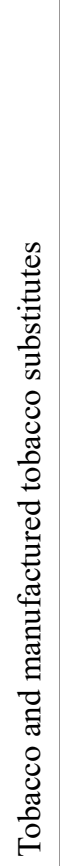 \\
\hline
\end{tabular}


Prior to EU membership, this was clearly evident, but it was not due to trade restrictions, as it had been significantly reduced by then. This also made the connection more effective. After accession, the positive developments in administrative processes and other achievements in the free flow of production factors were mainly able to increase the volume of trade and, at the same time, reduce the concentration of bilateral trade. The positive effect of this continues to this day. This proves that the structure of the external process is polarized, which can greatly reduce exposure to a country.

Besides the examination of concentration, the competitiveness of the product groups is also interesting. For quantifying comparative advantages, numerous indicators can use the Balassa index. In light of this, the asymmetric disproportionateness of the Balassa index, the RSCA indicator gives commensurable results. Aggregated RSCA values that are calculated using the weight of each product group in the total quantity of commodities traded present order between the countries. Table 2 contains the corrected $R S C A$ values, giving an insight into how competitiveness changed at a country level.

Table 2 shows the values of the $R S C A$, based on which it is possible to determine the products for which it is possible to determine a higher competitiveness potential (grey) under current conditions. Only products that have a higher added value will be able to compete, mainly in processed products. Raw materials and bulk products, due to a high volume of transport costs, are not competitive in this relationship. Hypothesis $\mathrm{H} 2$ is confirmed. That's why the Miscellaneous edible preparations category is competitive for both export and imperial countries. It is noteworthy that, although there is a significant difference between the volumes of foreign trade in each country, they were able to market a competitive product in almost the same number of categories in 2018. In the case of HU and PL, 8 categories are the most competitive from UK imports. In the case of products shipped to the UK, 11 categories from PL, 9 from HU, 8 from $\mathrm{CZ}$ and 5 from SK can be considered competitive. Hypothesis $\mathrm{H} 3$ is confirmed.

\section{SUMMARY}

While there is yet no agreement on the terms of Brexit, it is already clear that it will have a significant trade impact on the EU, as a whole. In the case of agricultural products, market transformation is also expected. In this process, the V4 countries look small, but due to reversal effects, serious consequences can also be expected in their case, too. As a result, the recently constantly expanding agricultural and food trade may undergo transformation. Good news for these countries is that the structure of commodity trade, which is not too concentrated, does not depend on certain product groups from British consumers alone.

Due to the heterogeneous and diverse trade relationship, they will be less exposed to acquisitions due to the Brexit, as it will be possible to sell any surplus to other existing markets. It is also a positive phenomenon that there are currently several product groups that now seem competitive. Though their number is not much, in these cases one can expect that British traffic may be more stable and predictable even in the case of a hard Brexit or no deal scenario. 


\section{BIBLIOGRAPHY}

Balassa Bela. 1965. Trade liberalisation and „revealed” comparative advantage. The Manchester School 33 (2): 99-123.

BBC. 2016. EU referendum results, http://www.bbc.com/news/politics/eu_referendum/results, access: 01.07.2019.

Dalum Bent, Keld Laursen, Gert Villumsen. 1998. Structural change in OECD export specialisation patterns: De-specialisation and 'Stickiness'. International Review of Applied Economics 12 (3): 423-443.

EC (European Commission). 2017. Brexit negotiations. The Article 50 negotiation process and principles for the United Kingdom's departure from the European Union, https://ec.europa.eu/ commission/brexit-negotiations_en, access: 21.06.2019.

EC (European Commission). 2019a. 'No-deal' Brexit preparedness: European Commission takes stock of preparations and provides practical guidance to ensure coordinated EU approach http://europa.eu/rapid/press-release_IP-19-2052_hu.htm, access: 12.04.2019.

EC (European Commission). 2019b. The EU-UK Withdrawal Agreement Brussels, 11.4.2019. COM(2019) 194 final, https://ec.europa.eu/commission/sites/beta-political/files/com_2019_194_ withdrawal_agreement.pdf, access: 12.04.2019.

European Council (2019): Brexit, https://www.consilium.europa.eu/en/policies/eu-uk-after-referendum/ access: 01.07.2019.

Eurostat. 2019 International Trade Database Access (ComExt), epp.eurostat.ec.europa.eu/newxtweb/, access: 20.05.2019.

Poór Judit. 2010. Érték- ésáralapú módszerek a külkereskedelmi versenyképesség mérésében a magyarmagyar hústermékek külkereskedelmének piacán, Doktori $(\mathrm{PhD})$ értekezés (Value-based and price-based methods for measuring the competitiveness of foreign trade in the foreign trade market of Hungarian meat products. Doctoral (PhD) Dissertation). University of Pannonia Keszthely.

Vásáry Miklos. 2018. The expected impact of Brexit for Visegrád Countries. Annals of the Polish Association of Agricultural and Agribusiness Economists XX (5): 224-230. DOI: 10.5604/01.3001.0012.6713.

Vásáry Miklos. 2019. Impact of Brexit on the trade of Hungarian agricultural and food products; Agriculture without borders. [In] 17th Wellmann International Scientific Conference, 8 May 2019. The University Of Szeged Faculty Of Agriculture, Hungary.

Vox.com. 2019. Boris Johnson, the frontrunner to be the UK's next prime minister, explained https://www.vox.com/2019/6/10/18638824/boris-johnson-tory-leader-prime-minister-brexit, access: 21.06.2019. 


\section{$* * *$ \\ WPŁYW BREXITU NA STOSUNKI HANDLOWE W SEKTORZE ROLNO-SPOŻYWCZYM W KRAJACH EUROPY WSCHODNIEJ}

Słowa kluczowe: Zjednoczone Królestwo, Brexit, handel, Grupa Wyszehradzka

\section{ABSTRAKT}

Celem artykułu jest stwierdzenie, które gałęzie handlu produktami rolno-spożywczymi pomiędzy państwami Grupy Wyszehradzkiej a Zjednoczonym Królestwem są zagrożone wskutek Brexitu. 23 czerwca 2016 roku Zjednoczone Królestwo, w drodze referendum, zdecydowało o wyjściu z Unii Europejskiej, jednak do tej pory proces opuszczania struktur unijnych nie zakończył się, mimo że powinno to nastąpić do 29 marca 2019 roku. Tym samym, Brexit pozostaje niepewny i nie wiadomo, na jakich warunkach nastąpi wyjście z Unii Europejskiej. Z powodu braku umowy końcowej, możliwe jest jedynie stwierdzenie, które obecne konkurencyjne sektory mogłyby pozostać konkurencyjnymi w przyszłości. Badania konkurencyjności mogą dać wskazówki dotyczące oczekiwanych skutków. W odniesieniu do produktów o niższej wartości konkurencyjnej, oczekuje się spadku obrotów ze względu na zmiany przepisów lub podwyższenie ceł. $Z$ analizy długoterminowej wartości handlowych w sektorze rolno-spożywczym uzyskiwanych przez strony, wynika wyraźnie, że rynki są w wystarczającym stopniu zdywersyfikowane. Dlatego wyjście Zjednoczonego Królestwa z Unii Europejskiej nie będzie niosło znaczących konsekwencji dla państw Grupy Wyszehradzkiej. W kwestii relacji handlowych, oczekuje się, że produkty wysoko przetworzone pozostaną produktami konkurencyjnymi także w przyszłości.

AUTHOR

MIKLOS VASARY, PHD

ORCID: 0000-0003-4501-6367

Budapest Metropolitan University

Institute of Economics and Business Science

H-1148 Budapest, Nagy Lajos király útja 1-9, Hungary 